\title{
Effects of Bank Specific Factors on Stock Returns of Listed Commercial Banks in Kenya
}

\author{
Sheila Wamicwe ${ }^{1}$, Dr. Tobias Olweny, Ph.D² \\ ${ }^{1,2}$ School of Business, Jomo Kenyatta University of Agriculture and Technology, Kenya
}

\begin{abstract}
The objective of this study was to establish the effects of bank specific factors on stock returns of listed commercial banks in Kenya, with four specific objectives; to determine the effect of capital adequacy on stock returns of listed commercial banks in Kenya, to determine the effect of asset quality on stock returns of listed commercial banks in Kenya, to determine the effect of earnings ability on stock returns of listed commercial banks in Kenya and to determine the effect of liquidity on stock returns of listed commercial banks in Kenya. The Kenyan banking sector instability within the stock market has been of great concern as depicted by continuous fluctuations in the stock prices of listed banks. Studies undertaken in other stock markets displayed mixed findings and much concentration has been on the United States, Turkey and Indonesian stock markets. Hence, a study providing a Kenyan perspective on the link between banks' internal environment and stock returns of listed banks was crucial. The study was based on market portfolio theory, efficiency structure hypothesis and the buffer capital theory. The research targeted all the 11 listed commercial banks at the Nairobi Securities Exchange. Quarterly data was collected for the period 2010-2019. A pooled panel regression model was used in the estimation of the significance of the impact of the variables. Findings of the research established that capital adequacy and earnings had a significant effect on stock returns. The study recommends that commercial banks should improve their capital base and expand their asset quality through better loan management.
\end{abstract}

KEYWORDS: Bank specific factors, Stock returns, Nairobi Securities Exchange, Modern portfolio theory, CAMEL framework, Efficiency Structure

\section{INTRODUCTION}

In the modern business environment, investment in stocks has emerged as an attractive venture to both foreign and local investors (Adjasi \& Yartey, 2007). Stock as an investment is a viable option with large and small investors because of the ease of access and definite regulations (El Wassal, 2013). Investors put money into stocks due to their expectation of high returns or the company's acquisition. Stock markets are an important aspect in any country's economy due to their role in directing the required long-term capital from the investors' side to the borrowers' side, they therefore bring investors and savers on one hand while the borrowers are on the other (Kizito, 2012). Apart from channeling the funds, the stock markets at the same time can be used by policy makers as a barometer to measure economic growth (Okoli, 2012).

Thus, stock market gives rise to various stake holders such as the investors, borrowers and policy makers. The policy makers applied stock market estimates as a measure of how vulnerable an economy or market is (Van Rooij, Lusardi, \& Alessie, 2011). Investors on the other hand require their investments to yield profit and as a result, they monitor the behavior of the stocks in the various stock markets around the world. Furthermore, they also monitor the value of certain industries in specific fields to improve their decision-making capacity (Sushko \& Turner, 2018). Borrowers are another set of stakeholders who monitor the stock price movements for their future borrowing purposes.

Banks, being the main financial intermediaries in an economy play the role of redistribution of individual and collective savings into other sectors of the economy which need the finances. Banks that are effective at recirculating these finances improves the nation's economy (Amer, Moustafa, \& Eldomiaty, 2011). The economy is made up of different interrelated sectors that work together to enhance service delivery. The banking industry plays a key role in circulating cash to all these sectors. The sector is highly profitable and well-regulated due to its impact in a country's financial system. This is what attracts both private and public investors in the stock markets (Nyantakyi, Sy, \& Kayizzi-mugerwa, 2015).

Therefore, prior to investing in stocks, it is paramount to ensure that the investor is good at observing stock markets to ensure that the correct investment is made to ensure huge stock returns. Several factors influence the productivity of stock investments and they include firm specific factors, economic factors (both macroeconomic and microeconomic factors) and government policies Sumantyo and Tresna (2017). It is therefore necessary for all stakeholders hoping to 
invest in stocks, including borrowers and governments to understand stock price movements and trends since these factors significantly influence stock prices and incomes. Since stock price movements affect the stakeholders differently and depends on various factors which include firm (in this case, bank) specific (internal or microeconomic) factors such as earnings per share, dividend per share and external factors such as macroeconomic variables and government policies, the stock market players must strive to make informed decisions based on the expected effects of these factors on the stock prices (Tache, 2016).

\section{MAIN OBJECTIVE}

The main aim of this study was to determine the relationship between bank-specific factors and the stock returns of listed commercial banks in Kenya.

\section{A. Specific objectives}

i) To establish the effect of capital adequacy on the stock returns of listed commercial banks in Kenya.

ii) To establish the effect of asset quality on the stock returns of listed commercial banks in Kenya.

iii) To establish the effect of earnings on the stock returns of listed commercial banks in Kenya.

iv) To analyze the effect of liquidity on the stock returns of listed commercial banks in Kenya.

\section{THEORETICAL REVIEW}

\section{A. Modern Portfolio Theory}

This theory was advanced by Harry Markowitz in 1952. Until 1950s, the John Burr Williams present value model was the most appreciated guide to investors hoping to invest in individual stocks. Harry M. Markowitz was a doctoral student of economics at University of Chicago, noticed that financial literature at that time did not factor the impact of risk. He also noted a general lack of understanding of impact of risk at portfolio level. He decided to research this subject and eventually published the results in this seminal paper called Portfolio Selection. Using defensible logic (statistics, mathematical formulas and graphs), through his thesis, he introduced the mean-variance model which uses variance of past returns as a proxy for risk and mean past returns as one of the indicators of expected returns. His studies also led to the development of the notion that efficient portfolios are those which yield the highest returns while encountering the least amount of risk. He was among the first scholars to identify the and advocate for the impact of diversification (Megginson, 1996, p. 325). His thesis did not change the world, however, his recognized book, Portfolio Selection: Efficient Diversification of Investments led to a change in the way investors approached risky investments. This paper and the book altogether became known as the Modern Portfolio Theory (MTP) by Harry M. Markowitz (Kamisetty, 2014). The Capital Asset Pricing Model (CAPM) was born from studies by William Sharpe, John Lintner, and Jan Mossin (1962), who expounded on Markowitz' and Tobin's works
(Megginson, 1996, p. 325). This model was an important evolutionary step in the theory of capital markets equilibrium. This model advocated for the valuation of securities as a function of systematic risk. The CAPM was instrumental to Sharpe (1964) in his development of the Efficient Frontier and Capital Market Line concepts. His model was so significant that he won the Nobel prize for his contribution to the field of economics. In 1965, Lintner (1965) used the CAPM to propose the concept of deriving company value from the quality of shares. Mossin then advanced the CAPM in 1966 by specifying quadratic utility functions (Megginson, 1996, p. 327). There have been developments in the field since then, but none have had as much an impact on different MPT approaches as the works mentioned above (Mangram, 2013).

Generally, modern portfolio theory as an investment theory bases itself on the idea that risk-averse investors have the capacity to design and maintain portfolios optimized to realize the highest amount of profits at the lowest level of market risk. According to the theory, risk is one of the requirements for high forms of rewards (Persson, Lejon, \& Kierkegaard, 2007). The MPT posits that investors build portfolios off of risk taking and risk aversive behavior for the eventual trade off(s) (Markowitz, 1952). It assumes that it is in human nature to take a certain amount of risk with the hope of realizing a specific level of return. This results in individuals having portfolios whose assets are designed to realize the highest returns while being exposed to the least amount of risk. Such portfolios tend to have a high degree of diversification making their overall management quite simple since the individual assets are exposed to the least amount of risk in the markets.

Firm specific variables and macroeconomic variables have a significant impact on the overall performance of businesses within their operating environments (Pandey, 2009). These differences in the operating environment impact the businesses' ability to realize returns on the projects that they have made investments in, resulting in increased income fluctuations. Increased uncertainty results in increased risk that the value of certain assets may plummet.

\section{B. Efficiency Structure Hypothesis}

This theory emerged from studies by Demsetz $(1973,1974)$ and it posits those high returns are results of the firm having certain specific advantages over their competitors. This advantage increases their managerial efficiency leading to increased profitability (Peltzman, 1977). Demsetz (1973) was among the first scholars to come up with an alternative explanation on the relationship between market structure and performance. In the financial industry, this hypothesis noted that efficient banks operate with the least cost while reporting increased income. It posits that such institutions are influential in the economy and control a large part of the market share. Different efficiency ratios are also the reason for varied levels of competitive positioning although all 
business operate in the same economic environment with similar regulations and standards to maintain.

Smirlock (1985), in agreement with the efficiency hypothesis, noted that market share is the driver of efficiency. He opined that there was efficiency hypothesis in situations where there is significant positive correlation between market share and profitability ratios. Accordingly, having a larger market share shows increased market power. However, Shepherd (1986) countered this system of thought by postulating that companies source market power from the supremacy of traders, rather than the individual market. This line of thinking led to the development of the Relative Market power (RMP) hypothesis. This theory hypnotizes that bank with the largest market share have the largest portfolios in the market and as a result use their power in the market to change prices of various classes of assets, resulting in profit generation. Therefore, according to this hypothesis, individual market shares determine who has the market power and determine the market imperfections.

Berger (1995), in his studies noted that it would be more effective to split the efficiency hypothesis into X-efficiency (XE) and scale efficiency (SE) hypotheses. The X-efficiency hypothesis maintains that efficiently managed banks incur less expenses than their competitors, leading to increased ability to realize profits. Such institutions gain an extended market share which consequently increases their concentration in the market. The banks with better $\mathrm{X}$ efficiency and are larger in terms of market shares also have higher concentration. According to this hypothesis, performance differences are a result of the different levels of scale efficiency as opposed to management quality.

Nzongang and Atemnkeng (2006) stress the impact of the balanced portfolio theory in highlighting different aspects of performance within banking and financial institutions. This is because according to the hypothesis, bank profitability, the composition of their respective portfolios, and shareholder returns are a result of the quality and nature of their management and the policy decisions which they make (Homma, Tsutsui, \& Uchida, 2014). As a conclusion, the theories demonstrated that banks' financial performance is a factor of various factors both internal and external to the bank. According to this study, internal factors are the bank specific factors. The efficient-structure theory also included two hypotheses: The X-efficiency hypothesis which argues for the efficiency of the management in driving the bank to realize profit margins and the scale efficiency hypothesis which argues that difference in profits is realized since different banks acquire varying scales of operation which results in a reduction of costs. This in turn plays a key role in the value of returns realized (Kongiri, 2012).

\section{Buffer Theory of Capital Adequacy}

Under the buffer theory of capital adequacy, banks will hold more capital than is necessary. As banks approach the minimum capital requirement, they aim to increase the capital, resulting in the creation of capital buffers. These buffers can then be used to cater for unexpected expenses should the bank become liable for a breach of one of the regulations (Von Thadden, 2004). These buffers are surplus to the firm and banks hold them over and above the minimum capital requirement (Jokipii \& Milne, 2011). This theory was developed by Calem and Rob (1996) and it posits that when banks approach the minimum capital ratio, the managements have increased motivation to increase capital held, this reduces the risk of getting fined by regulatory authorities should they breach any of the capital requirements.

Calem and Rob (1999) in improving on this theory claimed that breaching the regulatory provisions will lead to penalties. Banks will hold more capital to avoid falling below legal capital requirements. They also observed a U-shaped relationship between capital and risk taking for banks is formed. For the undercapitalized banks, they take more risks knowing that bankruptcy cost can be shifted over to Federal Deposit Insurance Corporation. Rime (2001) and Lindquist (2004) further determined that banks with ample capital invested in risky portfolios to generate higher profits that would be used to improve their capital position. Banks increase their capital when faced with higher portfolio thus keeping up their capital buffer.

Similarly, Gropp and Heider (2009) noted that this excess capital plays various roles including promotional, protective, regulatory and operational. Promotional function was explained by how banks ensure that they have enough capital to ensure growth through expansion and meet the stakeholder's expectations, hence promoting economic growth. The protective function was related to the banks' ability in cushioning itself against unforeseen losses and ensuring business continuity and reliability. Operational function was related to the support of banks activities and ensuring high volumes that lead to institutional gains. The regulatory function was explained by the management ensuring that adequate capital was held to absorb any unanticipated losses hence protecting the banks from breach of capital requirements (Volkov, 2010).

The theory is key to this study since it explains the reason and need for holding excess capital. Adequate capital reduces the volume of unexpected fines and penalties, ensures that the banks do not breach minimal capital requirements and allows for expansion of the bank's service offering. Together with effective management, it results in increased income for the bank and its shareholders. Holding excess capital allows for exploration into new business ventures without necessarily diverting finances from other departments.

\section{IV.EMPIRICAL REVIEW}

\section{A. Capital Adequacy and Stock Returns of Commercial Banks}

Jheng, Latiff, Keong and Chue (2018) assessed the Malaysian economy to determine how capital adequacy ratio relates to stock prices of the region's main banks. Adopting a 
descriptive research design, the study focused on 8 companies and collected data reported between 2005 and 2014. The study found no significant relationship between the two variables. The implication of these findings is that CAR which had been set up to preserve public confidence did not have any impact on public confidence. The study concluded that it was possible that CAR was not able to limit the risk of failures of a bank as a bank could have great financial distress while maintaining high capital adequacy ratio. According to the study, the findings implied that no amount of capital was a substitute for sound risk and capital management. Furthermore, in terms of public confidence, the capital adequacy ratio was not able to impact the public confidence. Hence, during financial crisis times, a good capital adequacy ratio might not have the persuasive power to stop a bank run. Odongo (2013) looked into the Kenyan market to determine whether stock prices were affected after the changes in the country's capital adequacy requirements. The study used event study research design and collected data from 9 banks. The study considered the events of one month prior and after an event date, 19th December 2008. It was reported that the announcement of capital adequacy requirements was negatively received since, post announcement, the value of stocks reduced drastically. These findings implied that investors disliked for capital adequacy regulations in the market. The loss in confidence in the financial system led to the study recommending that in the future, it may be necessary for the policy makers to consider how the firms will perform in the market with the introduction of such stringent measures. Considering that these measures would have a cumulative negative effect on the economy should be a deterrent to instituting harsh corporate actions.

\section{B. Asset Quality and Stock Returns of Commercial Banks}

Dubey and Kumari (2016) looked into the Indian market in an assessment on the impact of non-performing assets on stock market returns. A descriptive study design was adopted on a census of 39 institutions. Data for the study covered the period 2001-2015. Non-performing assets and advances were noted to negatively influence returns. Finding a negative relationship between NPA and returns was expected, however, finding a negative relationship between advances and returns was contrary to empirical literature. Conclusions were that increasing advances to management and various members of the team had negative effects on returns, meaning that banks should be cautious when increasing advances. On the other hand, NPAs weakened the bank's financial positioning.

Hashem and Alduneibat (2017) carried out their study in Jordan to investigate how non-performing loans impacted the ability of the banks to increase dividend payout to shareholders. The study adopted a descriptive analytical approach. The study focused on 15 listed banks and collected data from a ten-year period between 2005 - 2015. NPLs were noted to significantly reduce income from stocks. The study recommended that the banks in the region improve on their NPL reporting since this information significantly influences the behavior of investors.

\section{Earnings Ability and Stock Returns of Commercial Banks}

Rjoub, Civcir, and Resatoglu (2017) sought to determine micro and macroeconomic factors which determine prices of stocks of Turkish banks. The study applied a descriptive study design. The period span was from 1995: Q3 to 2015: Q4. The sample consisted of 7 banks listed in Istanbul Stock Exchange. Earning ability was noted to positively and significantly influence stock returns. An increase in the ratio of interest income to total assets improved profit ratios which resulted in an increase in the value of the stocks. Capital adequacy and liquidity were determined to have minimal effects on the prices of stocks. Asset quality and management quality had significant negative impacts on stock prices. In other words, poor bank management impacts the banks' ability to maintain healthy loan policies and this has a significant negative impact on the value and quality of its assets (outstanding loans). Because of the poor management and wrong lending decisions, Turkey experienced severe banking crises in the early 2000s.

Sujarwo (2015) analyzed the effect of banks' performance on their stock prices, selecting to focus on 31 banks which were in operation between 2011 and 2013. A causal explanatory study design was employed. Results showed that earnings ability, which was measured by net operating margin significantly improved the value of the banks' stocks. The study confirmed that when markets witnessed an improvement in the value of earnings, it resulted in an appreciation in the value of the stock prices. It determined that potential investors looked at profitability results as a sign of healthy operating companies where their investments would appreciate. This potential for increased returns in investment resulted in increased trading of particular shares over others since more people are buying more shares with the hope of selling them in the future and realizing the profits. Hence, earnings had individual significance towards the bank stock price.

\section{Liquidity and Stock Returns of Commercial Banks}

Heryanto (2016) assessed companies at the Indonesian Stock Exchange with the aim of determining whether liquidity ratios impact stock returns of banks. The study applied a descriptive study design on a population of 29 banks. Data was sought from reports which ranged from 2009 to 2010. Of the entire population, a sample of 26 banks was taken. The study found that liquidity negatively and significantly impacted the stock returns of the banks. This was similar to findings by Sitorus and Elinarty (2017) who found that liquidity had a negative influence towards the growth of stock prices of Indonesian banks. The study used dividend payout as a measure of stock growth and spanned from 2011 until 
2014. The study applied an explanatory research design on a population of 30 banks.

Anwaar (2016) assessed how overall performance impacted returns of stocks of companies listed at the FTSE-100 Index London, UK over the period 2005 to 2014. The study applied a descriptive study design on a sample of 30 firms. Earnings ability improved stock returns of the banks while liquidity as measured by quick ratio was noted to have minimal effects on stock returns. Rjoub, Civcir, and Resatoglu (2017) conducted a study focusing on the effect of micro and macroeconomic determinants of stock prices in the Turkish banking sector. The study adopted a panel data approach and the findings showed that micro and macroeconomic determinants of stock prices in Turkish banking sector.

\section{METHODOLOGY}

\section{A. Research Design}

A descriptive research design was applied. The descriptive research design was used due to its ability to depiction the actual nature of the subjects under study in their present environments. Kothari, (2004) notes that this type of research design focuses on analyzing complex variables and revealing any association that may exist between them. This design in particular allowed the researcher to describe and present accurate profiles of the level of capital adequacy, asset quality, earnings ability, liquidity and stock returns of the banks under study so that a true picture of the study variables in these banks was painted.

Furthermore, by conducting complex analyses mainly through inferential analysis, the use of this design allowed the researcher to make inferences from the data pertaining the relationships that exist between the study variables (Cooper and Schindler, 2003). By revealing the causal relationship existing between the variables, the researcher was able to establish how bank specific characters impact the value of returns of bank stocks in Kenya. This design was also easy to plan and execute, making it easy for the researcher to collect and analyze real-time data pertaining to the issues in the research.

\section{B. Target Population}

Sekaran, (2006) defined a population as the total collection of elements which a researcher uses to make inferences from. This study's population consisted of all the 11 banks listed at the Nairobi Securities Exchange (NSE, 2016; Central Bank of Kenya, 2018). A census of all the 11 banks was taken due to the minimal population which is relatively cheap to manage and source data from.

\section{Data Collection Instrument and Procedures}

The study sourced secondary data across a ten-year period. The data was retrieved from financial reports from the companies, as well as from existing reports within the CBK and NSE databases. The study utilized panel data from 2010 to 2019. This study period had been considered since it consisted of periods when banks under study experienced times of stability and also turmoil. Furthermore, this period had witnessed several major developments and changes within the banking sector such as interest capping and heightened financial innovations that were likely to affect some of the bank specific factors such as earnings and efficiency and ultimately their stock market performance. The period also encompassed major events such as the placing under receivership of some banks and also fluctuating political risk that are likely to affect the operations of the banks under study. Moreover, the NSE had undergone various crucial developments especially in legal and institutional changes which were aligned with global standards affecting listed firms.

\section{Capital Adequacy}

Objective one was assessing the impact of capital adequacy on stock returns. The following equation was used in determination of the capital adequacy ratio:

$$
\text { Capital Adequacy Ratio }=\frac{\text { Total Capital }}{\text { Total Risk Weighted Assets }}
$$

Quarterly panel data on total capital and risk weighted assets was sourced from financial reports of the banks and other relevant regulatory bodies. The researcher relied on online official reports posted in the banks' official websites and only visited the banks physically if need arose. The period of collecting the data was one month and the ratio was expressed in percentage form before the analysis was carried out.

\section{Asset Quality}

Objective two was establishing the impact of asset quality on stock returns of the banks. Asset quality was assessed as a factor of non-performing loans ratio expressed as the ratio of total non-performing loans to gross advances as follows:

Non - performing loans ratio

$$
=\frac{\text { Total Non }- \text { Performing Loans }}{\text { Gross Total Advances }}
$$

Quarterly panel data pertaining to total non-performing loans and gross advances of the banks for 10-year period from 2010 to 2019 was collected from the banks' financial reports. The researcher relied on online official reports posted in the banks' official websites and only visited the banks physically if need arose.

\section{Earnings Ability}

Objective three was to determine how earnings ability impact stock returns of the banks. The proxy of earnings ability in this study was the ratio of interest income to total income.

$$
\text { Earnings Ability }=\frac{\text { Interest Income }}{\text { Total Income }}
$$

Quarterly panel data related to the interest incomes and total incomes of the banks was sourced from the banks' official reports and statements for 10-year period from 2010 to 2019. The researcher relied on online official reports posted in the 
banks' official websites and only visited the banks physically if need arose.

\section{Liquidity}

The last objective was to determine how liquidity impacts stock returns of the banks. Liquidity in this study was measured in terms of total loans to total deposits.

$$
\text { Liquidity }=\frac{\text { Total Loans }}{\text { Total Deposits }}
$$

Quarterly panel data of the banks' total loans and total deposits was sourced from the statements and reports from the banks. The period of collecting the data was one month and the data was expressed in percentage form before the analysis was carried out.

\section{Stock Returns}

The stock returns of the banks were measured using the bank stock prices where quarterly averages of the stock prices of the banks at the NSE were used. The ratio was expressed in percentage form before the analysis as follows:

$$
\text { Stock Returns }=\frac{P_{t}-P_{t-1}}{P_{t-1}}
$$

Where, $\mathrm{P}_{\mathrm{t}-1}$ is quarterly average stock price of the previous quarter while $\mathrm{P}_{\mathrm{t}}$ is quarterly average stock price at a particular quarter.

\section{Model Specification}

A dynamic panel data model illustrated in equation 1.1 was used to determine the relationships between the variables. A dynamic time- series panel data regression model was adopted to demonstrate the relationship between bank specific factors and stock returns among Kenyan banks listed at the NSE. This type of model was adopted since it allows for analysis of change in outcomes across different time periods (Hsiao, 2014). This type of data illustrated the changes at the individual firms' level, established time order of variables and showed how relationships emerged (Frees, 2004).

The general empirical model used in the study was defined as follows:

$$
Y_{i t}=\alpha+\beta X_{i t}+\varepsilon_{i t}
$$

Where: $Y_{i t}$ was the dependent variable denoting stock returns at time $\mathrm{t}$; i denoted the observation (bank), $\mathrm{i}=1 \ldots, 11$ while $\mathrm{t}$ was the time period, $\mathrm{t}=2010, \ldots \ldots, 2019 ; X_{i t}$ denoted a vector of independent variables, $\beta$ were coefficients to be estimated, $\alpha$ was a constant term, and $\varepsilon_{i t}$ was a composite error term.

Equation 1.1 was expanded to obtain equation 1.2 which was used for estimation.

$$
\begin{aligned}
& S R_{i t}=\propto_{\circ}+\beta_{1} C A_{i t}+\beta_{2} A Q_{i t}+\beta_{3} E A_{i t}+\beta_{4} L M_{i t}+
\end{aligned}
$$

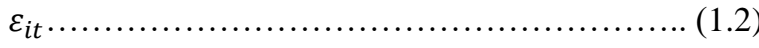

$$
\begin{aligned}
& \mathrm{SR}_{\mathrm{it}}=\text { Stock Returns of bank } i \text { at time } t \\
& \propto_{\mathrm{o}}=\text { Intercept } \\
& \beta \mathrm{s}=\text { Coefficients of the explanatory variables. }
\end{aligned}
$$$$
\text { Where: }
$$

Subscript $i=$ Banks (cross-section dimensions) ranging from 1 to 11 ;

Subscript $t=$ Years (time-series dimensions) ranging from 2010 to 2019 ;

$\varepsilon_{\mathrm{it}}=$ Composite error term of the model.

$\mathrm{CA}_{\mathrm{it}}=$ Capital Adequacy of bank $i$ at time $t$

$\mathrm{AQ}_{\mathrm{it}}=$ Asset Quality of bank $i$ at time $t$

$\mathrm{EA}_{\mathrm{it}}=$ Earnings Ability of bank $i$ at time $t$

$\mathrm{L}_{\mathrm{it}}=$ Liquidity of bank $i$ at time $t$

\section{E. Hausman Tests}

Upon accounting for violations of classical linear assumptions, the Feasible Generalized Least Square estimation was carried out. Panel data estimation can be carried out with the help of three models: Pooled Ordinary Least Square (OLS) regression model, Fixed Effect (FE) model and Random Effect (RE) model. All three models were applied to the data before selecting the most appropriate model. This study settled on FE or RE models after encountering unfavorable limitations with the Pooled Ordinary Least Square (OLS) regression model.

\section{F. Normality Tests}

The normality assumption (ut $\sim \mathrm{N}(0, \sigma 2)$ ) is necessary for the conduction of single or joint hypothesis testing on the model parameters (Brooks, 2018). The Bera and Jarque, (1981) tests of normality were carried out to determine whether the data was from a normally distributed sample. If the p-value is less than 0.05 , the null of normality at the $5 \%$ level was rejected.

\section{G. Multicollinearity Test}

The multicollinearity test helped in identifying any high intercorrelations among the independent variables which might make it difficult for the researcher to determine the importance of a given predictor. Variance inflation factor was preferred over the Pearson correlation coefficients when measuring for multicollinearity. All VIF factors that were between 1 and 10 were adopted since they indicated zero multicollinearity.

\section{H. Autocorrelation}

The term autocorrelation may be defined as correlation between members of a series of observations ordered in time [as in time series data] or space [as in cross-sectional data]. The presence of serial correlation would be a clear indication that the variables in the model violate the assumptions of the regression (Honnery et al., 2004). The study applied the Durbin-Watson test to determine the correlation.

\section{Heteroscedasticity}

The nature of the data raises concerns of heteroscedasticity. The classical linear regression model assumed that the error term is homoscedastic, that is, it has constant variance. Inconsistent error variances pointed to the existence of heteroscedasticity, which would limit the results of the analysis. The Likelihood ratio tests was applied. Presence of heteroscedasticity would reject the null hypothesis that the 
error variance is homoscedastic. A FGLS model would be executed if the researcher determined heteroscedasticity in the panel data.

\section{J. Stationarity Test}

The nature of the data prompted the stationarity test. Unit root tests were carried out on all the study variables. The Levin, Lin \& Chu $t^{*}$ statistic test was executed to test the properties of the data series. The Levin, Lin \& Chu $t^{*}$ statistic tested the null hypothesis of non-stationarity against the alternative hypothesis of stationarity. The rejection criterion was that if Levin, Lin \& Chu $\mathrm{t}^{*}$ statistic is less than the $\mathrm{p}$ value at $1 \%$, $5 \%, 10 \%$ level of significance, then the null hypothesis is rejected.

Ho: The variable is non-stationary (i.e. it has a unit root)

$H a$ : The variable is stationary (i.e. it has no unit root)

Differencing was undertaken for those variables found to be non-stationarity.

\section{RESULTS AND DISCUSSIONS}

\section{A. Descriptive Statistics}

The study focus was the 11 listed commercial banks in Kenya. The study utilized secondary research data collected for the period 2010-2019 with capital adequacy, asset quality, earnings, liquidity and stock returns being extracted. The summary of the descriptive analysis is discussed in Table I below. The key for interpretation is as follows; SR-stock returns, CA - capital adequacy, AQ - asset quality, EA earnings and LQ - liquidity.

Table I: Summary of Research Observations

\begin{tabular}{llllll}
\hline & SR & CA & AQ & EA & LQ \\
\hline Mean & 0.0085 & 0.1902 & 0.0793 & 0.7577 & 0.8388 \\
& 66 & 7 & 99 & 98 & 9 \\
Median & - & 0.1789 & 0.0637 & 0.7543 & 0.8137 \\
& & 33 & 89 & 88 & 7 \\
Maxim & 0.4678 & 0.4873 & 0.5133 & 0.9629 & 1.5909 \\
um & 56 & 05 & 18 & 92 & 49 \\
Minim & - & 0.0266 & 0.0102 & 0.4644 & 0.3367 \\
um & 0.7519 & 82 & 31 & 63 & 91 \\
& 9 & & & & \\
Std. & 0.1386 & 0.0543 & 0.0827 & 0.0948 & 0.2048 \\
Dev. & 26 & 67 & 13 & 68 & 77 \\
Skewne & - & 1.4188 & 3.4814 & 0.1313 & 1.0349 \\
SS & 0.0373 & 53 & 33 & 94 & 13 \\
& 3 & & & & \\
Kurtosi & 5.1208 & 9.2328 & 16.457 & 2.8098 & 4.7651 \\
s & 62 & 87 & 37 & 5 & 2 \\
\hline
\end{tabular}

The study findings presented indicate that listed commercial banks had attained an average of 0.008 in their stock returns between the period 2010-2019. This shows that investors are generally making gains on their investments. The research also finds that the capital adequacy averaged at $19 \%$. According to Zidan and Maitah, (2014) these results show that the firms are able to meet all their financial obligations, therefore increasing their strength in the market. The findings also show that on average the asset quality was $7.9 \%$. This represents a rather high-risk profile. According to Jeanne and Svensson, (2007) a bank's risk profile is evaluated by its asset quality. The higher the asset quality the lower the risk profile. Earnings are an indication of the firm's competitive positioning among its peers Athanasoglou, Brissimis, and Delis, (2008). The study results found that the average earnings among the listed commercial banks was 0.75 . This was also the case for the median, showing that the average companies exhibited around $75 \%$ earnings ability. The research also showed that the maximum liquidity was 1.59 compared to a minimum of 0.33 . These were all in line with the Central Bank's regulation which require the minimum liquidity to be $20 \%$.

\section{B. Correlation Analysis}

The research conducted correlation analysis to establish the type of association between the bank-specific factors and the stock returns of the listed banks. The correlation tests have values ranging from -1 to +1 which are an indication of the strength of the interaction between the study variables.

Table II: Correlation Results

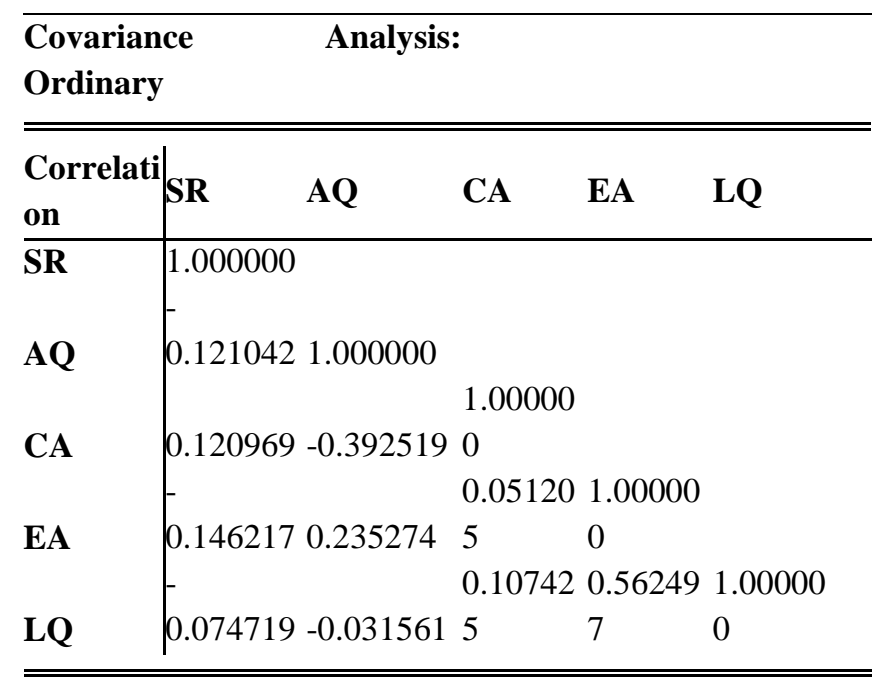

The first objective of the study was to establish the effect of capital adequacy on the stock returns of the listed commercial banks. Findings of the correlation tests indicated that capital adequacy had a weak positive effect on the stock returns of the listed commercial banks $(r=0.1209)$. Similar results were attained by Agave, Efrani, and Rosmalena, (2018) who found out that capital adequacy ratio was positively associated with stock gains. However, Odongo (2013) found out that capital adequacy was negatively associated with stock prices in Kenya.

The study second objective analyzed the effect of asset quality on the stock returns of the listed commercial banks in Kenya. The results of the study established that asset quality has a negative and insignificant effect on the stock returns of the listed commercial banks in Kenya ( $r=-0.1210)$. This is 
consistent with Başarır and Ülker (2015) who found out that asset quality was negatively associated with stock returns of commercial banks.

The third objective of the study was to establish the effect of earnings on the stock returns of the listed commercial banks. Findings of the correlation tests indicated that earnings had a negative and significant effect on the stock returns of the listed commercial banks $(r=-0.14621)$. The findings are not in line with Mashoka, (2013) who found out that banks earnings had a positive relationship with the stock returns. Anwaar, (2016) also noted that earnings ability improved the stock returns.

The study fourth objective analyzed the effect of liquidity on the stock returns of the listed commercial banks in Kenya. The results of the study established that liquidity has a negative and insignificant effect on the stock returns of the listed commercial banks in Kenya $(r=-0.0747)$. These results are in line with Anwaar, (2016) who found minimal effect of liquidity on stock returns among listed UK banks.

\section{Normality Tests}

This study adopted the The Bera and Jarque (1981) tests of normality to examined if the data was from a normally distributed sample. The tests criterion examines whether the significance value is less than 0.05 .

Table III: Normality Results

\begin{tabular}{llllll}
\hline \multicolumn{1}{c}{ SR } & $\begin{array}{c}\text { Capital } \\
\text { AdequacyQuality }\end{array}$ & $\begin{array}{c}\text { Asset } \\
\text { Earnings Liquidity }\end{array}$ \\
\hline Jarque-Bera & 82.56655 & 859.8599 & 4209.012 & 1.928937 & 135.6635 \\
Probability & 0.7040 & 0.000000 & 0.000000 & 0.381186 & 0.000000 \\
Observations 440 & 440 & 440 & 440 & 440 \\
\hline
\end{tabular}

The test results indicated that except for stock returns $(\mathrm{J}-\mathrm{B}=$ 82.5665 , Prob $=.704)$ and Earnings $(\mathrm{J}-\mathrm{B}=1.9289$, Prob $=$ .381) the null of normal distribution based on the Jarque-Bera test was accepted for the other variables.

\section{Hausmann Specification Test}

The study adopted the Hausmann specification tests to determine the suitable model between fixed and random effects to apply in the research. The test results are presented below.

Table IV: Hausman Specification Test

Correlated Random Effects - Hausman Test

Equation: EQ01

Test cross-section random effects

\begin{tabular}{llll}
\hline \hline Test Summary & $\begin{array}{l}\text { Chi-Sq. } \\
\text { Statistic }\end{array}$ & $\begin{array}{l}\text { Chi-Sq. } \\
\text { d.f. }\end{array}$ & Prob. \\
\hline \hline Cross-section random & 0.136403 & 5 & 0.9997 \\
\hline \hline
\end{tabular}

Cross-section random effects test comparisons:

\begin{tabular}{lllll} 
Variable & Fixed & Random & Var(Diff.) Prob. \\
\hline \hline D_AQ & 0.449323 & 0.421403 & 0.010170 & 0.7819 \\
D_CA & 0.528892 & 0.530533 & 0.000960 & 0.9578 \\
& - & & & \\
D_EA & 0.378080 & -0.376937 & 0.000131 & 0.9205 \\
& - & & & \\
D_LQ & 0.257120 & -0.257359 & 0.000063 & 0.9760
\end{tabular}

The Hausman test is distributed as chi-square with 1 degree of freedom. From the results above the probability of the cross section random effects was 0.9997 , which is greater than 0.05 implying that it's appropriate to adopt random effects model.

\section{E. Panel Regression Analysis}

The study main purpose was to determine the relationship that exists between bank-specific factors and the stock returns of listed commercial banks in Kenya. The study applied unbalanced panel regression analysis. This was deemed suitable since the research relied on panel observations extracted from the listed commercial banks in Kenya between the period 2010Q1-2019Q4. Before undertaking the panel analysis, the study conducted specification tests to establish the most suitable model between the fixed effects and random effects that was to be applied.

Based on the results of the specification tests the study adopted the random effects model in the regression analysis to determine the relationship between bank-specific factors and the stock returns of listed commercial banks in Kenya.

Table V: Regression Summary

Dependent Variable: D_SR

Method: Panel EGLS (Cross-section random effects)

Swamy and Arora estimator of component variance

\begin{tabular}{lllll}
\hline Variable & Coefficient & $\begin{array}{l}\text { Std. } \\
\text { Error }\end{array}$ & $\begin{array}{l}\text { t- } \\
\text { Statistic }\end{array}$ & Prob. \\
\hline $\begin{array}{l}\text { Capital } \\
\text { Adequacy }\end{array}$ & 0.28297 & 0.13198 & 2.14 & 0.032 \\
Asset & & & & \\
Quality & -0.0778 & 0.09064 & -0.86 & 0.391 \\
Earnings & -0.19541 & 0.08791 & -2.22 & 0.026 \\
Liquidity & -0.00871 & 0.03928 & -0.22 & 0.824 \\
C & 0.11629 & 0.05642 & 2.06 & 0.039
\end{tabular}

\section{Effects Specification}

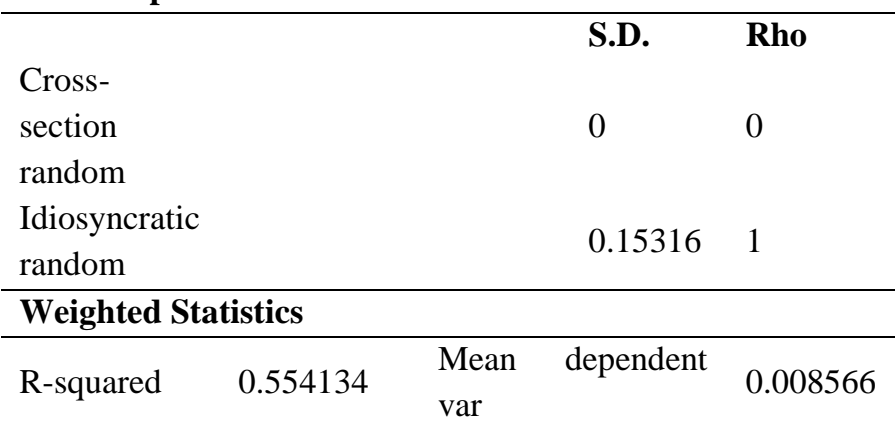


"Effects of Bank Specific Factors on Stock Returns of Listed Commercial Banks in Kenya"

\begin{tabular}{|c|c|c|c|}
\hline $\begin{array}{l}\text { Adjusted R- } \\
\text { squared }\end{array}$ & 0.504468 & S.D. dependent var & 0.1378 \\
\hline $\begin{array}{l}\text { S.E. of } \\
\text { regression }\end{array}$ & 0.097003 & Sum squared resid & 3.716775 \\
\hline F-statistic & 11.15719 & $\begin{array}{l}\text { Durbin-Watson } \\
\text { stat }\end{array}$ & 1.654918 \\
\hline
\end{tabular}

The regression analysis indicated there is a positive and significant relationship between bank specific factors and the stock returns of the listed commercial banks in Kenya (Rsquared $=0.5541$, Prob $=.000<.05)$. The findings indicate that holding other factors constant, $55.41 \%$ of the stock returns of listed commercial banks in Kenya are determined by the bank-specific factors.

\section{CONCLUSIONS}

The study was able to confirm the presence of a statistically significant and positive influence of bank specific factors on the stock returns of listed commercial banks. The research concludes that the capital adequacy, asset quality, earning and liquidity do have a positive relationship with stock returns. Concerning the first objective, the research concluded that capital adequacy had a positive and significant effect on the stock returns of commercial banks. The findings showed that the total capital to total risk weighted assets were a significant predictors of stock returns. The study also concluded that asset quality had a negative and insignificant effect on the stock returns of the listed commercial banks in Kenya. The findings implied that the level of total non-performing loans to the gross advances were not a significant determinant of stock returns.

The third objective examined the earnings of the commercial bank and based on the results the research concluded that earnings had a negative and significant influence on the stock returns. The findings showed that an increase in the interest income to the total income significantly influences the stock returns. The study further concluded that liquidity had a negative and insignificant relationship with the stock returns of the listed commercial banks. The research findings indicated that total loans to total deposits of the banks did not have a significant predictive power on the stock returns.

\section{REFERENCES}

1. Adeolu, M. A. (2014). Asset quality and bank performance: A Study of Commercial Banks in Nigeria. Lagos State University.

2. Adjasi, C. K., \& Yartey, C. A. (2007). Stock market development in Sub-Saharan Africa: Critical issues and challenges (No. 7-209). International Monetary Fund.

3. Agave, B., Efrani, M., \& Rosmalena, S. (2018). Effect of financial performance of banking companies to stock return: Empirical studies on banking companies listed in Indonesia Stock Exchange in the year of $2016-2015$. International
Journal of Economics, Business and Management Research, 2(3), 377-394.

4. Agbada, A. O., \& Osuji, C. C. (2013). The efficacy of liquidity management and banking performance in Nigeria. International Review of Management and Business Research, 2(1), 223-233.

5. Al-Muharrami, S., \& Matthews, K. (2009). Market power versus efficient-structure in Arab GCC banking. Applied Financial Economics, 19(18), 1487-1496.

6. Amahalu, N., Abiahu, M. F. C., Christian, O., \& Chinyere, O. (2016). Determinants of capital structure: Empirical evidence from quoted electrical and electronic technology firms in Nigeria (20102015).

7. Amer, H. H., Moustafa, W., \& Eldomiaty, T. (2011, June). Determinants of operating efficiency for lowly and highly competitive banks in Egypt. In Cambridge Business \& Economics Conference ISBN (Vol. 1333678436).

8. Anwaar, M. (2016). Impact of firms' performance on stock returns: Evidence from listed companies of FTSE-100 Index London, UK. Global Journal of Management and Business Research: Accounting and Auditing, 16(6), 31-39.

9. Anyanzwa, J. (2017). In 2016, it was a poor showing on the NSE. The East African. Retrieved from: https://www.theeastafrican.co.ke/business/-poorshowing-on-the-NSE-in-2016/2560-3885792ahg49p/index.html

10. Banafa, A. S. A. (2016). The effect of leverage, liquidity, and firm size on financial Performance of listed non-financial firms in Kenya (Doctoral dissertation, COHRED, Business administration, JKUAT).

11. Basarir, Ç., \& Ülker, Y. (2015). Relationship between financial performance of banks and stock revenues: Panel data analysis. Journal of Applied Finance and Banking, 5(5), 171-183.

12. Baum, C. (2006). An introduction to Modern Econometrics, Stata Press 341 pages.

13. Bera, A., \& Jarque, C. (1981). Efficient tests for normality, homoscedasticity and serial independence of regression residuals. Economic Letters, 7(4), 313-318.

14. Berger, A. N., \& Hannan, T. H. (1997). Using efficiency measures to distinguish among alternative explanations of the structure-performance relationship in banking. Managerial Finance, 23(1), 6-31.

15. Brooks, C. (2008). Introductory Econometrics 2nd edition. Cambridge University Press.

16. Brueggeman, W. B., \& Fisher, J. D. (2011). Real estate finance and investments (pp. 5-6). New York, NY: McGraw-Hill Irwin. 
17. Burns, N., \& Grove, SK. (2003). The practice of nursing research: Conduct, critique and utilization. Toronto Press.

18. Chen, X., Kim, K. A., Yao, T., \& Yu, T. (2010). On the predictability of Chinese stock returns. PacificBasin Finance Journal, 18(4), 403-425.

19. Cheruiyot, R. K. (2016). The Effect of asset quality on profitability of commercial banks in Kenya (Doctoral dissertation, School of Business, University of Nairobi).

20. Chortareas, G. E., Girardone, C., \& Ventouri, A. (2009). Efficiency and productivity of Greek banks in the EMU era. Applied Financial Economics, 19(16), 1317-1328.

21. Chu, E. (1997). Impact of earnings, dividends and cash flows on stock returns: Case of Taiwan's stock market. Review of Quantitative Finance and Accounting, 9(2), 181-202.

22. Cooper, D., \& Schindler, P. (2003). Business Research Methods, 8th Edition, McGraw-Hill Irwin.

23. Dang, U. (2011). The CAMEL rating system in banking supervision. A case study. Retrieved from: http://urn.fi/URN:NBN:fi:amk-2016123019231

24. De Bock, R., \& Demyanets, M. A. (2012). Bank asset quality in emerging markets: Determinants and spillovers (No. 12-71). International Monetary Fund.

25. Demsetz, H (1973). Industry Structure, Market Rivalry and Public Policy. Journal of law and Economics 16(1), 3.

26. El Wassal, K. A. (2013). The development of stock markets: In search of a theory. International Journal of Economics and Financial Issues, 3(3), 606-624.

27. Elliott, D. J. (2014). Bank liquidity requirements: An introduction and overview. The Brookings Institution.

28. Eltivia, N., Sudarma, M., \& Saraswati, E. (2014). The effect of cost efficiency on stock performance of listed banks in Indonesia. Int.J.Eco. Res., 5(2), 50-56.

29. Elton, E. J., Gruber, M. J., Brown, S. J., \& Goetzmann, W. N. (2009). Modern portfolio theory and investment analysis. John Wiley \& Sons.

30. Fiordelisi, F. (2007). Shareholder value efficiency in European banking. Journal of Banking \& Finance, 31(7), 2151-2171.

31. Frees, E. (2004). Longitudinal and panel data. Cambridge University Press pp 467.

32. Gay, R. D. (2016). Effect of macroeconomic variables on stock market returns for four emerging economies: Brazil, Russia, India, and China. The International Business \& Economics Research Journal (Online), 15(3), 119.
33. Gonçalves, J. D. B. (2013). Bank capital and stock performance around the subprime lending crisis (Doctoral dissertation, NSBE-UNL).

34. Gropp, R., \& Heider, F. (2010). The determinants of bank capital structure. Review of Finance, 14(4), 587-622.

35. Gudmundsson, R., Ngoka-Kisinguh, K., \& Odongo, M. T. (2013). The role of capital requirements on bank competition and stability: The case of the Kenyan banking industry. Kenya Bankers Association-KBA Centre for Research on Financial Markets and Policy Working Paper Series.

36. Hashem, F., \& Alduneibat, K. A. (2017). The impacts of non-performing loans upon the prices of stocks in Jordanian commercial banks. Accounting and Finance Research, 6(1), 139.

37. Heryanto, M. (2016). Effect of liquidity and profitability to bank stock return in Indonesia Stock Exchange (IDX). International Journal of Academic Research in Accounting, Finance and Management Sciences, 6(3), 131-138.

38. Hsiao, C. (2014). Analysis of Panel data. Cambridge University Press pp 562.

39. Ibe, S. O. (2013). The impact of liquidity management on the profitability of banks in Nigeria. Journal of Finance and Bank Management, 1(1), 37 48.

40. In'airat, M. H. S. (2018). The effect of internal and external factors on stock market prices-evidence from Saudi Arabia. The Business \& Management Review, 9(3), 413-423.

41. Jheng, T. J., Latiff, A. R. A., Keong, O. C., \& Chue, T. (2018). The relationship between capital adequacy ratio and stock price of banking institutions: Evidence from Malaysia. Management, 5(3), 67-87.

42. Karmakar, S., \& Gambacorta, L. (2017). Leverage and Risk Weighted Capital Requirements (No. 2017/09). ISEG-Lisbon School of Economics and Management, REM, Universidade de Lisboa.

43. Kasman, S., Vardar, G., \& Tunç, G. (2011). The impact of interest rate and exchange rate volatility on banks' stock returns and volatility: Evidence from Turkey. Economic Modelling, 28(3), 1328-1334.

44. Kasomo, D. (2006). Research methods in Humanities and Education. Egerton University Press.

45. Kimunge, M. W. (2017). Effect of interest rate capping on stock returns of listed commercial banks at the Nairobi Securities Exchange. Unpublished MSC Project, University of Nairobi.

46. Kongiri, A. T. (2012). Effects of CAMEL Variables on Bank Efficiency: A Panel Analysis of Kenyan Commercial Banks. Unpublished MBA Project, University of Nairobi. 
47. Lindquist, K. G. (2004). Banks' buffer capital: how important is risk. Journal of International Money and Finance, 23(3), 493-513.

48. Lintner, J. (1965). Security prices, risk, and maximal gains from diversification. The Journal of Finance, 20(4), 587-615.

49. Markowitz, H. (1952). Portfolio selection. The Journal of Finance, 7(1), 77-91.

50. Mensi, S., \& Zouari, A. (2010). Efficient structure versus market power: theories and empirical evidence. International Journal of Economics and Finance, 2(4), 51-164.

51. Mostafa, H. T., \& Boregowda, S. (2014). A Brief Review of Capital Structure Theories. Research Journal of Recent Sciences, ISSN, 2277, 2502.

52. Muchiri, N. L. (2014). The relationship between liquidity management and stock market return: Evidence from commercial banks. Unpublished MBA Project, University of Nairobi.

53. Mugenda, A., \& Mugenda, O. (2013). Research methods: Quantitative and qualitative approaches. ACTS press.

54. Muriungi, K. M. (2016). Effect of commercial bank failure announcement on stock returns of banks listed at the Nairobi Securities Exchange. Unpublished MSC Project, University of Nairobi.

55. Musyoka, B. F. (2017). The effect of capital adequacy on the financial performance of commercial banks in Kenya. Unpublished MBA Project, University of Nairobi.

56. Mwangi, M. N., \& Iraya, C. (2014). The effects of liquidity on financial performance of deposit taking microfinance institutions in Kenya. MBA Research Project, University of Nairobi.

57. Mwanza, K. (2017, December 18). Non-performing loans in local banks hit 10-year high. Business Daily.

58. Mwaurah, I., Muturi, W., \& Waititu, A. (2017). The influence of credit risk on stock returns. International Journal of Scientific and Research Publications, 7(5), 575-584.

59. Ngira, A. R., Oluoch, J., \& Kalui, M. (2014). Effects of Liquidity Management on the Security Market Performance of Companies Listed at the Nairobi Securities' Exchange. IOSR Journal of Applied Physics. 6 (I), 58-61.

60. Odongo, F. O. (2013). Stock price reaction to changes in capital adequacy regulation in the Kenyan banking sector. Unpublished MBA Project, University of Nairobi.

61. Olalekan, A., \& Adeyinka, S. (2013). Capital adequacy and banks' profitability: an empirical evidence from Nigeria. American International Journal of Contemporary Research, 3(10), 87-93.
62. Olweny, T., \& Shipho, T. M. (2011). Effects of banking sectoral factors on the profitability of commercial banks in Kenya. Economics and Finance Review, 1(5), 1-30.

63. Ongore, V. O., \& Kusa, G. B. (2013). Determinants of financial performance of commercial banks in Kenya. International Journal of Economics and Financial Issues, 3(1), 237-252.

64. Pandey, I. M. (2009). Financial management, (9thed.). New Delhi: Vikas Publishing House PVT Limited

65. Piskorski, T., Seru, A., \& Witkin, J. (2015). Asset quality misrepresentation by financial intermediaries: evidence from the RMBS market. The Journal of Finance, 70(6), 2635-2678.

66. Qiu, M., \& Song, Y. (2016). Predicting the direction of stock market index movement using an optimized artificial neural network model. PloS One, 11(5), e0155133.

67. Rime, B. (2001). Capital requirements and bank behaviour: Empirical evidence for Switzerland. Journal of Banking \& Finance, 25(4), 789-805.

68. Rjoub, H., Civcir, I., \& Resatoglu, N. G. (2017). Micro and macroeconomic determinants of stock prices: The case of Turkish banking sector. Journal for Economic Forecasting, (1), 150-166.

69. Sharpe, W. F. (1964). Capital asset prices: A theory of market equilibrium under conditions of risk. The Journal of Finance, 19(3), 425-442.

70. Shepherd, W. G. (1986). Tobin's q and the Structureperformance Relationship: Comment. The American Economic Review, 76(5), 1205-1210.

71. Sitorus, T., \& Elinarty, S. (2017). The Influence of Liquidity and Profitability toward the growth of Stock price mediated by the Dividen Paid out (Case in banks listed in Indonesia Stock Exchange). Journal of Economics, Business \& Accountancy Ventura, 19(3), 377-392.

72. Sujarwo, A. A. (2015). The impact of Indonesia's banks performance towards banks' stock price (Listed in Indonesia Stock Exchange from 20162018) using CAMEL analysis. iBuss Management, 3(2).

73. Tache, G. M. (2016). The effect of earnings and dividends on share prices of firms listed at the Nairobi Securities Exchange (Doctoral Dissertation, University of Nairobi).

74. Uzhegova, O. (2010). The relative importance of bank-specific factors for bank profitability in developing economies. Mediterranean Journal of Social Sciences, 6(3), 277-288.

75. Vardar, G (2013), Efficiency and stock performance of banks in transition countries: Is there a relationship? International Journal of Economics and Financial Issues, 3(2), 355-369. 